\title{
Effects of corn silage hybrids and dietary nonforage fiber sources on feed intake, digestibility, ruminal fermentation, and productive performance of lactating Holstein dairy cows ${ }^{1}$
}

\author{
M. S. Holt, C. M. Williams, C. M. Dschaak, J.-S. Eun, ${ }^{2}$ and A. J. Young \\ Department of Animal, Dairy, and Veterinary Sciences, Utah State University, Logan 84322-4815
}

\begin{abstract}
This experiment was conducted to determine the effects of corn silage hybrids and nonforage fiber sources (NFFS) in high forage diets formulated with high dietary proportions of alfalfa hay $(\mathrm{AH})$ and corn silage (CS) on ruminal fermentation and productive performance by early lactating dairy cows. Eight multiparous Holstein cows (4 ruminally fistulated) averaging $36 \pm 6.2 \mathrm{~d}$ in milk were used in a duplicated $4 \times 4$ Latin square design experiment with a $2 \times 2$ factorial arrangement of treatments. Cows were fed 1 of 4 dietary treatments during each of the four 21-d replicates. Treatments were (1) conventional CS (CCS)-based diet without NFFS, (2) CCS-based diet with NFFS, (3) brown midrib CS (BMRCS)-based diet without NFFS, and (4) BMRCSbased diet with NFFS. Diets were isonitrogenous and isocaloric. Sources of NFFS consisted of ground soyhulls and pelleted beet pulp to replace a portion of $\mathrm{AH}$ and $\mathrm{CS}$ in the diets. In vitro 30 -h neutral detergent fiber (NDF) degradability was greater for BMRCS than for CCS (42.3 vs. $31.2 \%$ ). Neither CS hybrids nor NFFS affected intake of dry matter (DM) and nutrients. Digestibility of N, NDF, and acid detergent fiber tended to be greater for cows consuming CCS-based diets. Milk yield was not influenced by CS hybrids and NFFS. However, a tendency for an interaction between CS hybrids and NFFS occurred, with increased milk yield due to feeding NFFS with the BMRCS-based diet. Yields of milk fat and $3.5 \%$ fat-corrected milk decreased when feeding the BMRCS-based diet, and a tendency existed for an interaction between CS hybrids and NFFS because milk fat concentration further decreased by feeding NFFS with BMRCS-based diet. Although feed efficiency (milk/DM intake) was not affected by CS hybrids and NFFS, an interaction was found between CS hybrids and NFFS because feed efficiency increased when NFFS was fed

Received May 6, 2010.

Accepted July 6, 2010.

${ }^{1}$ Approved as Journal Paper Number 8204 of the Utah Agricultural Experiment Station, Utah State University, Logan.

${ }^{2}$ Corresponding author: jseun@usu.edu
\end{abstract}

only with BMRCS-based diet. Total volatile fatty acid production and individual molar proportions were not affected by diets. Dietary treatments did not influence ruminal $\mathrm{pH}$ profiles, except that duration $(\mathrm{h} / \mathrm{d})$ of $\mathrm{pH}$ $<5.8$ decreased when NFFS was fed in a CCS-based diet but not in a BMRCS-based diet, causing a tendency for an interaction between CS hybrids and NFFS. Overall measurements in our study reveal that high forage NDF concentration (20\% DM on average) may eliminate potentially positive effects of BMRCS. In the high forage diets, NFFS exerted limited effects on productive performance when they replaced AH and CS. Although the high quality $\mathrm{AH}$ provided adequate NDF (38.3\% DM) for optimal rumen fermentative function, the low $\mathrm{NDF}$ concentration of the $\mathrm{AH}$ and the overall forage particle size reduced physically effective fiber and milk fat concentration.

Key words: brown midrib corn silage, nonforage fiber source, alfalfa hay, lactational performance

\section{INTRODUCTION}

Typical lactating dairy diets in the Intermountain West (i.e., Utah, Idaho, Wyoming, Montana, and parts of Arizona and Nevada) contain more alfalfa hay $(\mathbf{A H})$ than corn silage (CS), and baled AH is commonly fed to provide 50 to $75 \%$ of the dietary forage with total forage levels averaging 45 to $55 \%$ of the dietary DM. Although both forages provide the needed fiber components, alfalfa and CS complement each other nutritionally: CS is high in energy, whereas alfalfa is high in protein. Howard (1994) suggested that factors such as forage particle length, diet DM, protein degradability, dietary starch concentration, and calcium levels are important factors to consider when determining the optimum balance of alfalfa and CS in rations. Making decisions on the dietary ratio between alfalfa and CS on a nutrition basis is becoming more complicated because many corn hybrids have been developed with specific plant traits that enhance their value as a nutrient source, such as the brown midrib (BMR) CS hybrid. The BMRCS is characterized by its lower lignin concentration and 
higher fiber digestibility than conventional CS (CCS; Oba and Allen, 1999). Although concerns with lower yields of the BMR hybrids exist (Eastridge, 1999), the lower yield can be somewhat offset by the higher forage quality having more digestible fiber. This allows cows to be fed more forage and less concentrate, which will increase ruminal $\mathrm{pH}$ and improve overall ruminal functionality. In most the studies done on BMRCS, lactating dairy cows were fed the BMR hybrid CS at high dietary proportions, but only a few studies included alfalfa as hay or silage at low proportions (Ebling and Kung, 2004; Kung et al., 2008). Because high quality AH is more readily available than CS in the Intermountain West, the nutritional benefits of feeding BMRCS must be assessed with a relatively high dietary proportion of $\mathrm{AH}$ in lactating dairy rations.

Feed costs account for 35 to $50 \%$ of the total costs to produce milk (Ipharraguerre and Clark, 2003). Thus, dairy producers attempt to minimize the costs of feeding their herds, particularly when milk prices are low, to maximize the efficiency of production. Nonforage fiber sources (NFFS) are plant byproducts produced by extraction of starch, sugar, or other valuable nonfibrous constituents. In many areas of the United States, NFFS are readily available at competitive prices. Hence, feeding these byproducts to dairy cows may represent an excellent opportunity to reduce feed costs. Traditionally, NFFS have been used as sources of concentrate, because many NFFS have relatively high $\mathrm{NE}_{\mathrm{L}}$ and moderate CP concentrations (Stern and Zeimer, 1995). Alternatively, NFFS can be successfully used as a source of fiber in rations for dairy cattle when forages are either of poor quality or in short supply. In view of the aforementioned reasons and others, it appears that feeding NFFS to dairy cows is a practice that will continue to increase in popularity among dairy nutritionists and producers.

We hypothesized that BMRCS would have limited effects on digestibility, ruminal $\mathrm{pH}$ and fermentation measurements, and lactational performance when fed with a relatively high dietary proportion of high quality AH. The objectives of this study were to assess nutritive merits of BMRCS compared with CCS when fed to high forage lactating diets, and to determine if NFFS would be effectively used in CCS-based diet to maintain similar productive performance in cows fed BMRCS-based diet.

\section{MATERIALS AND METHODS}

The dairy cows used in this study were cared for according to the Live Animal Use in Research Guidelines of the Institutional Animal Care and Use Committee at Utah State University.

\section{Cows and Experimental Diets}

Eight multiparous lactating Holstein cows were used; 4 cows were surgically fitted with ruminal cannulas. Days in milk ranged from 26 to $42 \mathrm{~d}$ and from 32 to 39 d for noncannulated and cannulated cows, respectively, at the start of the experiment. Average BW was $633 \pm$ $83.6 \mathrm{~kg}$ at the beginning of the experiment and $666 \pm$ $80.6 \mathrm{~kg}$ at the end of the experiment.

The design of the experiment was a double $4 \times 4$ Latin square, with each period lasting $21 \mathrm{~d}$ (14 d of treatment adaptation and $7 \mathrm{~d}$ of data collection and sampling). The cows were allocated to squares according to whether they were surgically cannulated, and the 2 squares were conducted simultaneously. Within square, cows were randomly assigned to a sequence of 4 diets. A $2 \times 2$ factorial arrangement was used; CCS or BMRCS (Table 1) was combined without or with NFFS to form 4 treatments: CCS-based diet without NFFS, CCS-based diet with NFFS, BMRCS-based diet without NFFS, and BMRCS-based diet with NFFS (Table 2). Nonforage fiber sources consisted of a 50:50 (DM basis) blend of ground soyhulls and pelleted beet pulp. The diets that contained NFFS had $48.6 \%$ forage, $43.0 \%$ concentrate, and $8.4 \%$ NFFS, and the forage consisted of $48.5 \% \mathrm{AH}$ and $51.5 \% \mathrm{CS}$ on a DM basis (Table 2). The diets without NFFS had $57.0 \%$ forage and $43.0 \%$ concentrate with the forage consisting of $45.5 \% \mathrm{AH}$ and $54.5 \% \mathrm{CS}$ on a DM basis (Table 2). The diets are typical for high-producing dairy cows in northern Utah with the inclusion of Rumensin (Elanco Animal Health, Greenfield, IN) and Megalac (Church \& Dwight Co. Inc., Princeton, NJ). Rations were formulated based on NRC (2001) recommendations to provide sufficient $\mathrm{NE}_{\mathrm{L}}, \mathrm{MP}$, vitamins, and minerals to produce $40 \mathrm{~kg} / \mathrm{d}$ of milk with $3.5 \%$ fat and $3.0 \%$ true protein.

Brown midrib corn hybrid (Mycogen F2F569, Mycogen Seeds, Indianapolis, IN) and a conventional corn hybrid (Pioneer 37K84, Pioneer Hi-Bred International Inc., Johnston, IA) were planted during spring 2009 on private property near Logan, Utah. Corn silages were harvested using a self-propelled forage harvester (model 6850, John Deere, Moline, IL) that applied lactic acid bacteria containing 90,000 cfu/g (Promote LC, Cargill, Minneapolis, MN) at a rate of $1.1 \mathrm{~g} / \mathrm{t}$ of fresh forage. A theoretical chop length of $0.95 \mathrm{~cm}$ was used with mechanical processing during harvesting. The mechanical processing was done using an automatic roller mill (Jaguar 900 model, Claas Ltd., Hansewinkel, Germany) designed for processing corn plants, which was attached to the forage harvester. Approximately $28 \mathrm{t}$ of each silage was placed in bag silos $(\mathrm{Ag} / \mathrm{Bag}$ International Ltd., Warrenton, OR) and ensiled for $60 \mathrm{~d}$. Alfalfa hay was prepared in large round bales and finely chopped 
Table 1. Chemical composition and particle size distribution of corn silages $(n=4)$

\begin{tabular}{lcccc}
\hline & \multicolumn{2}{c}{ Corn silage hybrid $^{1}$} & & \\
\cline { 2 - 2 } Item & CCS & BMRCS & SE & $P$-value \\
\hline Chemical composition & & & & \\
DM, \% & 34.0 & 35.6 & 0.44 & 0.01 \\
OM, \% of DM & 99.3 & 98.4 & 0.48 & 0.34 \\
CP, \% of DM & 7.36 & 7.24 & 0.62 & 0.52 \\
NDF, \% of DM & 41.2 & 41.7 & 0.85 & 0.62 \\
ADF, \% of DM & 23.4 & 23.3 & 0.73 & 0.93 \\
Acid detergent lignin, \% of DM & 2.70 & 1.93 & 0.095 & $<0.01$ \\
Particle size distribution & & & & \\
19 mm & 3.2 & 2.4 & 0.46 & 0.29 \\
8 mm & 79.4 & 76.1 & 0.94 & 0.07 \\
1.18 mm & 17.4 & 21.5 & 0.63 & 0.01 \\
Pan $_{\text {pef }}$ & 0 & 0 & - & - \\
peNDF $_{8.0}$ & 82.6 & 78.5 & 1.40 & 0.11 \\
\hline
\end{tabular}

${ }^{1} \mathrm{CCS}=$ conventional corn silage; BMRCS $=$ brown midrib corn silage.

${ }^{2}$ Particle size distribution was expressed as \% DM retained on sieves using the Penn State Particle Separator (Kononoff et al., 2003). pef $_{8.0}=$ physical effectiveness factor determined as the proportion of particles retained on top 2 sieves (Lammers et al., 1996). peNDF $_{8.0}=$ physically effective NDF determined as NDF concentration $(\% \mathrm{DM})$ of corn silage multiplied by pef . $_{8.0}$.

Table 2. Ingredient and chemical composition of experimental diets $(\mathrm{n}=4)$

\begin{tabular}{|c|c|c|c|c|}
\hline \multirow{2}{*}{ Item } & \multicolumn{4}{|c|}{ Experimental $\operatorname{diet}^{1}$} \\
\hline & \multicolumn{2}{|c|}{ CCS } & \multicolumn{2}{|c|}{ BMRCS } \\
\hline \multicolumn{5}{|l|}{ Ingredient, $\%$ of DM } \\
\hline Alfalfa hay & 26.0 & 23.6 & 26.0 & 23.6 \\
\hline BMRCS & - & - & 31.0 & 25.0 \\
\hline Soyhulls & - & 4.20 & - & 4.20 \\
\hline Beet pulp & - & 4.20 & - & 4.20 \\
\hline Canola meal & 5.89 & 5.89 & 5.89 & 5.89 \\
\hline Corn DDGS ${ }^{2}$ & 5.24 & 5.24 & 5.24 & 5.24 \\
\hline Soybean meal, $48 \% \mathrm{CP}$ & 5.04 & 5.04 & 5.04 & 5.04 \\
\hline Molasses & 2.10 & 2.10 & 2.10 & 2.10 \\
\hline Megalac ${ }^{3}$ & 1.59 & 1.59 & 1.59 & 1.59 \\
\hline Magnesium oxide & 0.14 & 0.14 & 0.14 & 0.14 \\
\hline Vitamins and trace minerals ${ }^{4}$ & 0.06 & 0.06 & 0.06 & 0.06 \\
\hline \multicolumn{5}{|l|}{ Chemical composition, \% of DM } \\
\hline DM, $\%$ & $53.9 \pm 0.98$ & $55.6 \pm 1.14$ & $55.8 \pm 2.24$ & $54.4 \pm 0.81$ \\
\hline $\mathrm{OM}$ & $91.6 \pm 0.17$ & $91.2 \pm 0.28$ & $91.5 \pm 0.51$ & $91.4 \pm 0.19$ \\
\hline $\mathrm{CP}$ & $18.0 \pm 1.03$ & $18.1 \pm 1.06$ & $18.1 \pm 1.06$ & $18.3 \pm 1.00$ \\
\hline NDF & $32.5 \pm 2.32$ & $32.4 \pm 2.30$ & $32.2 \pm 1.21$ & $32.2 \pm 2.00$ \\
\hline $\mathrm{ADF}$ & $19.2 \pm 1.60$ & $19.7 \pm 2.01$ & $19.1 \pm 1.37$ & $19.0 \pm 1.80$ \\
\hline $\mathrm{NE}_{\mathrm{L}},{ }^{5} \mathrm{Mcal} / \mathrm{kg}$ & 1.73 & 1.75 & 1.85 & 1.85 \\
\hline
\end{tabular}

${ }^{1} \mathrm{CCS}-\mathrm{NFFS}=$ conventional corn silage (CCS)-based diet without nonforage fiber sources (NFFS); CCS+NFFS = CCS-based diet with NFFS BMRCS-NFFS = brown midrib corn silage (BMRCS)-based diet without NFFS; and BMRCS+NFFS = BMRCS-based diet with NFFS

${ }^{2}$ Dried distillers grains with solubles.

${ }^{3}$ Church \& Dwight Co. Inc., Princeton, NJ.

${ }^{4}$ Formulated to contain (per kilogram of DM): $4.75 \mathrm{mg}$ of Se (from sodium selenate), $182 \mathrm{mg}$ of $\mathrm{Cu}$ (from copper sulfate), $732 \mathrm{mg}$ of Zn (from zinc sulfate), 10,369 IU of vitamin A, 1,185 IU of vitamin D, $150 \mathrm{IU}$ of vitamin E, and $19.6 \mathrm{~g}$ of Rumensin (Elanco Animal Health, Greenfield, IN). ${ }^{5}$ Based on tabular value (NRC, 2001). 
using a bale processor (Case/IH, model 8610, J. I. Case International, Racine, WI).

Cows were housed in individual tie stalls fitted with rubber mattresses and bedded with straw, and were fed a TMR for ad libitum intake with at least $10 \%$ of daily feed refusal. All cows were individually fed twice daily at 0830 and $1500 \mathrm{~h}$ with approximately $70 \%$ and $30 \%$ of total daily feed allocation at each feeding, respectively. Feed offered and refused was recorded daily, and daily samples were collected to determine DMI. Cows had free access to water.

Cows were milked twice daily at 0400 and $1600 \mathrm{~h}$. Milk production was recorded daily throughout the experiment. Cows were turned outside to a dry-lot for exercise for at least $1 \mathrm{~h}$ daily in the morning after being milked. Milk was sampled during the a.m. and p.m. milkings on 2 consecutive days (d 16 to $\mathrm{d} 17$ ) in each period. Milk samples were preserved with Broad Spectrum Microtabs II (D\&F Control Systems Inc., San Ramon, CA), and were stored at $4^{\circ} \mathrm{C}$. Individual milk samples were analyzed for fat, true protein, lactose, and MUN by the Rocky Mountain DHIA Laboratory (Logan, UT). Milk composition was expressed on weighted milk yield of a.m. and p.m. samples. Milk fat and protein yields were calculated by multiplying milk yield from the respective day by fat and protein concentration of the milk from an individual cow.

\section{Feed Sampling}

Corn silage, chopped $\mathrm{AH}$, and concentrates were sampled weekly to determine DM concentration. Diets were adjusted weekly to account for changes in DM concentration. Corn silage samples were collected on d 20 and 21 for particle size analysis by using the Penn State Particle Separator, as described by Kononoff et al. (2003), equipped with 3 sieves $(19,8$, and $1.18 \mathrm{~mm})$ and a pan. Physical effectiveness factor (pef) for CS was calculated as the sum of the proportion of DM retained on 2 sieves, 19 and $8 \mathrm{~mm}$ ( pef $_{8.0}$; Lammers et al., 1996). The physically effective NDF (peNDF) content of the CS was calculated by multiplying NDF concentration of the feed (DM basis) by pef 8.0 $\left(\mathbf{p e N D F}_{\mathbf{8 . 0}}\right)$.

Samples of the TMR fed and orts for individual cows were collected daily during the data collection period, dried at $60^{\circ} \mathrm{C}$ for $48 \mathrm{~h}$, ground to pass a $1-\mathrm{mm}$ screen (standard model 4; Arthur H. Thomas Co., Philadelphia, PA), and stored for subsequent analyses.

Analytical DM concentration of samples was determined by oven drying at $135^{\circ} \mathrm{C}$ for $3 \mathrm{~h}$; OM was determined by ashing, and $\mathrm{N}$ content was determined using an elemental analyzer (Leco TruSpec N, St. Joseph, MI; AOAC, 2000). The NDF and ADF concentrations were sequentially determined using an Ankom ${ }^{200 / 220}$ Fiber
Analyzer (Ankom Technology, Macedon, NY) according to the methodology supplied by the company, which is based on the methods described by Van Soest et al. (1991). Pretreatment with heat-stable amylase (Type XI-A from Bacillus subtilis; Sigma-Aldrich Corporation, St. Louis, MO) and sodium sulfite were used in the procedure for NDF determination. Acid detergent lignin was determined as outlined in AOAC (2000; method no. 973.18 , procedure $\mathrm{D}$ ); the samples were soaked in $12 M$ sulfuric acid for $3 \mathrm{~h}$ and thoroughly washed with boiling distilled water.

Feed DM and nutrient digestibility were measured during the last week in each period using acid-insoluble ash as an internal marker (Van Keulen and Young, 1977). Fecal samples (approximately $200 \mathrm{~g}$ wet weight) were collected for each cow from the rectum twice daily (a.m. and p.m.) every $12 \mathrm{~h}$, moving ahead $2 \mathrm{~h}$ each day for the $6 \mathrm{~d}$ of fecal sampling beginning on $\mathrm{d} 15$. This schedule provided 12 representative samples of feces for each cow. Samples were immediately subsampled (about $50 \mathrm{~g}$ ), composited across sampling times for each cow and each period, dried at $55^{\circ} \mathrm{C}$ for $72 \mathrm{~h}$, ground to pass a 1-mm screen (standard model 4, Arthur H. Thomas), and stored for chemical analysis. Apparent total-tract nutrient digestibilities were calculated from concentrations of acid-insoluble ash and nutrients in diets fed, orts, and feces.

\section{In Vitro NDF Degradation of Corn Silages}

The Daisy II in vitro fermentation system (Ankom Technology) was used to examine the NDF degradation of CS used in the lactation trial. Five hundred milligrams $( \pm 20 \mathrm{mg})$ of CCS or BMRCS was weighed into artificial fiber bags (\#F57, Ankom Technology), which were then heat-sealed. Ruminal fluid was collected 4 $\mathrm{h}$ after the morning feeding $(1100 \mathrm{~h})$ from 2 ruminally cannulated, lactating Holstein cows fed a TMR composed of CCS (22.4\%), chopped AH (43.2\%), rolled corn grain $(22.6 \%)$, and concentrate $(11.8 \%)$ on a DM basis. To prepare the ruminal fluid, ruminal contents were obtained from various locations within the rumen and composited. The ruminal contents were placed in sealed containers, transported to the laboratory, and strained through a polyester screen (pore size $355 \mu \mathrm{m}$; B. \& S. H. Thompson, Ville Mont-Royal, QC, Canada) under a stream of oxygen-free $\mathrm{CO}_{2}$. Four hundred milliliters of ruminal fluid ( $\mathrm{pH}$ of 6.2) was then added to each Ankom fermentation jar, together with $1,600 \mathrm{~mL}$ of anaerobic buffer prepared according to Hall et al. (1998), and fermentation was allowed to continue for $30 \mathrm{~h}$ at $39^{\circ} \mathrm{C}$. Bags were removed in quadruplicate (plus one empty bag) at $30 \mathrm{~h}$ of incubation, and washed under cold tap water until the excess water ran clear. Bags were dried 
at $55^{\circ} \mathrm{C}$ for $48 \mathrm{~h}$, and NDF degradation was determined using the same procedure described in feed sampling. The experiment was replicated on 4 occasions.

\section{Ruminal Fermentation Characteristics}

Ruminal $\mathrm{pH}$ was continuously measured for 2 consecutive days starting on d 18 using the Lethbridge Research Centre Ruminal pH Measurement System (LRCpH; Dascor, Escondido, CA) as described by Penner et al. (2006). Readings in $\mathrm{pH}$ buffers 4 and 7 were recorded before placing the $\mathrm{LRCpH}$ system in the rumen. Ruminal $\mathrm{pH}$ readings were taken every $30 \mathrm{~s}$ and stored by the data logger. After about $48 \mathrm{~h}$ of continuous $\mathrm{pH}$ measurement, the $\mathrm{LRCpH}$ was removed from the rumen and washed in $39^{\circ} \mathrm{C}$ water, and millivolt readings were recorded in $\mathrm{pH}$ buffers 4 and 7 . The daily ruminal $\mathrm{pH}$ data were averaged for each minute and summarized as minimum $\mathrm{pH}$, mean $\mathrm{pH}$, and maximum $\mathrm{pH}$. In addition, daily episodes, duration $(\mathrm{h} / \mathrm{d})$, and area $(\mathrm{pH} \times \min )$ when ruminal $\mathrm{pH}$ was $<5.8$ were calculated. The threshold 5.8 was assigned because it has been defined by others (Nocek, 1997; Maekawa et al., 2002; Beauchemin and Yang, 2005) to cause ruminal acidosis.

Ruminal contents were sampled from cannulated cows 0,3 , and $6 \mathrm{~h}$ after the a.m. feeding on d 20 and 21 . Approximately $1 \mathrm{~L}$ of ruminal contents was obtained from the anterior dorsal, anterior ventral, medial ventral, posterior dorsal, and posterior ventral locations within the rumen, composited by cow, and strained through a polyester screen (pore size of $355 \mu \mathrm{m}$ ). Five milliliters of the filtered ruminal fluid was added to $1 \mathrm{~mL}$ of $1 \%$ sulfuric acid and samples were retained for ammonia- $\mathrm{N}\left(\mathrm{NH}_{3}-\mathrm{N}\right)$ determination. Concentration of $\mathrm{NH}_{3}-\mathrm{N}$ in the ruminal contents was determined as described by Rhine et al. (1998). Another $5 \mathrm{~mL}$ of the filtered ruminal fluid was taken at $3 \mathrm{~h}$ after the a.m. feeding and added to $1 \mathrm{~mL}$ of $25 \%$ of meta-phosphoric acid, and the samples were retained for VFA determination. The VFA were quantified using a GLC (model 5890, Hewlett-Packard, Palo Alto, CA) with a capillary column $(30 \mathrm{~m} \times 0.32 \mathrm{~mm}$ i.d., $1 \mu \mathrm{m}$ phase thickness, Zebron ZB-FAAP, Phenomenex, Torrance, CA), and flame-ionization detection. The oven temperature was $170^{\circ} \mathrm{C}$ held for $4 \mathrm{~min}$, which was then increased by $5^{\circ} \mathrm{C} /$ min to $185^{\circ} \mathrm{C}$, and then by $3^{\circ} \mathrm{C} / \mathrm{min}$ to $220^{\circ} \mathrm{C}$, and held at this temperature for $1 \mathrm{~min}$. The injector temperature was $225^{\circ} \mathrm{C}$, the detector temperature was $250^{\circ} \mathrm{C}$, and the carrier gas was helium.

\section{Statistical Analyses}

Data were summarized for each cow by measurement period. All data were statistically analyzed using the mixed model procedure in SAS (SAS Institute, 2001). In vitro NDF degradation of CS was analyzed as a completely randomized design using a model that included CS hybrids as a fixed effect and experimental run as a random effect. Data for intake, digestibility, and milk production were analyzed with a model that included the effects of CS hybrids in the diet (CCS vs. BMRCS), group (noncannulated vs. cannulated cows), NFFS (without vs. with NFFS), and the CS $\times$ NFFS interaction. Cow, period, and cow by period by group were the terms of the random statement.

Data for VFA profiles were analyzed with a model that included the CS hybrids, NFFS, and the CS $\times$ NFFS interaction. Cow and period were the terms of the random statement. Data for $\mathrm{NH}_{3}-\mathrm{N}$ concentration were analyzed using the model described above except that the fixed effect of time after feeding was included using the repeated option. The covariance structure that resulted in the lowest values for the Akaike's information criteria and Schwartz's Bayesian criterion was used (Littell et al., 1998).

Residual errors were used to test main effects and interactions. Differences were considered significant at $P<0.05$, and trends were discussed at $P<0.15$. When the CS $\times$ NFFS interaction was $P<0.15$, contrasts were used to examine the effects of NFFS within CS hybrids using single degree of freedom contrasts. Contrasts were considered significant at $P<0.05$. Results are reported as least squares means.

\section{RESULTS}

Table 1 lists the chemical composition of forages fed during the experiment. Brown midrib CS had higher DM concentration than CCS (35.6 vs. 34.0\%). Mean concentrations of $\mathrm{CP}, \mathrm{NDF}$, and ADF were similar for the 2 silages at $7.3,41.5$, and $23.4 \%$ on a DM basis, respectively. As expected, BMRCS had a lower concentration of acid detergent lignin compared with CCS (1.93 vs. $2.70 \%$ on a DM basis).

A similar proportion of particles was present on the top screen $(>19 \mathrm{~mm})$ for CCS and BMRCS (Table 1), but a larger proportion of particles tended $(P=0.07)$ to remain on the middle screen $(>8 \mathrm{~mm})$ for CCS $(79.4 \%)$ than for BMRCS (76.1\%). Thus, a smaller proportion of particles remained on the bottom screen $(>1.18 \mathrm{~mm})$ for CCS (17.4\%) than for BMRCS (21.5\%). Consequently, pef $_{8.0}$ tended $(P=0.11)$ to be higher for CCS than for BMRCS, but peNDF ${ }_{8.0}$ was similar between CCS and BMRCS. In vitro NDF degradability of CS after $30 \mathrm{~h}$ of incubation was markedly higher for the BMRCS than the CCS (42.2 vs. $31.2 \%$; Figure 1).

The ingredients and chemical composition of experimental diets are listed in Table 2. Concentrations 
Table 3. Nutrient intake and total-tract digestibility of early lactation Holstein dairy cows fed conventional or brown midrib corn silage without or with nonforage fiber sources

\begin{tabular}{|c|c|c|c|c|c|c|c|c|}
\hline Item & \multicolumn{4}{|c|}{ Diet $^{1}$} & $\mathrm{SE}$ & & & \\
\hline \multicolumn{9}{|c|}{ Intake, $\mathrm{kg} / \mathrm{d}$} \\
\hline DM & 26.5 & 26.2 & 27.7 & 26.6 & 1.43 & 0.20 & 0.27 & 0.56 \\
\hline $\mathrm{OM}$ & 23.2 & 24.5 & 25.0 & 24.3 & 1.36 & 0.44 & 0.75 & 0.39 \\
\hline $\mathrm{ADF}$ & 4.75 & 5.25 & 5.04 & 4.98 & 0.375 & 0.96 & 0.30 & 0.21 \\
\hline \multicolumn{9}{|c|}{ Digestibility, \% } \\
\hline DM & 72.9 & 74.1 & 72.5 & 71.0 & 2.29 & 0.26 & 0.92 & 0.40 \\
\hline $\mathrm{OM}$ & 74.3 & 75.1 & 73.9 & 72.5 & 2.27 & 0.32 & 0.82 & 0.47 \\
\hline $\mathrm{N}$ & 75.7 & 76.8 & 74.7 & 73.7 & 1.73 & 0.11 & 0.94 & 0.40 \\
\hline NDF & 53.0 & 54.8 & 51.4 & 49.4 & 3.75 & 0.14 & 0.96 & 0.42 \\
\hline $\mathrm{ADF}$ & 49.9 & 53.2 & 48.2 & 45.6 & 4.12 & 0.06 & 0.88 & 0.23 \\
\hline
\end{tabular}

${ }^{1}$ CCS-NFFS = conventional corn silage (CCS)-based diet without nonforage fiber sources (NFFS); CCS+NFFS = CCS-based diet with NFFS; BMRCS-NFFS = brown midrib corn silage (BMRCS)-based diet without NFFS; and BMRCS+NFFS = BMRCS-based diet with NFFS.

${ }^{2} \mathrm{CS}=$ effect of hybrids of CS in the diet (CCS vs. BMRCS); NFFS = effect of dietary NFFS (without vs. with NFFS); and INT = interaction between CS and NFFS.

of $\mathrm{CP}, \mathrm{NDF}$, and $\mathrm{ADF}$ were similar across all dietary treatments.

Intake of DM averaged $26.8 \mathrm{~kg} / \mathrm{d}$ across all treatment diets and was not affected by diet (Table 3 ). Additionally, CS hybrids and NFFS did not influence intake of OM, N, NDF, and ADF. Digestibilities of DM and $\mathrm{OM}$ were similar in response to diets. However, digestibilities of $\mathrm{N}(P=0.11)$, NDF $(P=0.14)$, and ADF $(P=0.06)$ tended to increase by $2.8,6.9$, and $10.0 \%$, respectively, by feeding the CCS-based diet compared with the BMRCS-based diet. Feeding NFFS did not affect the digestibilities.

Milk yield averaged $42.3 \mathrm{~kg} / \mathrm{d}$ across all treatment diets, and it was not influenced by CS hybrids or NFFS

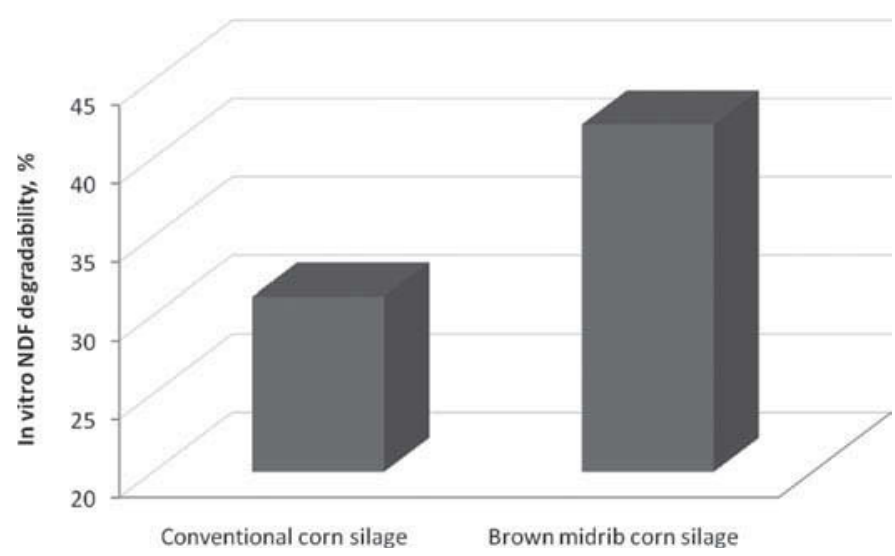

Figure 1. In vitro NDF degradability of corn silages used in lactation trial after $30 \mathrm{~h}$ of incubation with ruminal fluid $(\mathrm{n}=4$ for each mean; $P=0.03 ; \mathrm{SE}=3.15$ ).
(Table 4). Feeding NFFS to the CCS-based diet did not affect milk yield, whereas NFFS tended $(P=0.09)$ to increase milk yield when fed in the BMRCS-based diet, resulting in a tendency for a CS $\times$ NFFS interaction $(P=0.06)$. Yields of milk fat and 3.5\% FCM decreased by feeding the BMRCS-based diet. Diets did not affect milk protein yield. Feeding the BMRCS-based diet decreased milk fat concentration, and it was further decreased by feeding NFFS in the BMRCS-based diet, causing a tendency for a CS $\times$ NFFS interaction $(P$ $=0.07)$. Corn silage hybrids did not change concentrations of milk protein and lactose. However, feeding NFFS in the BMRCS-based diet decreased milk protein concentration, whereas NFFS in the BMRCS-based diet increased milk lactose concentration, resulting in an $\mathrm{CS} \times$ NFFS interaction or its tendency $(P=0.11)$, respectively. Concentration of MUN was not affected by diets.

Hybrids of CS and NFFS did not affect feed efficiency expressed as milk yield per DMI (Table 4). However, NFFS in the CSS-based diet tended to decrease $(P=$ 0.08) feed efficiency, whereas NFFS in the BMRCSbased diet increased feed efficiency, leading to a CS $\times$ NFFS interaction. The BMRCS-based diet increased feed efficiency when expressed as 3.5\% FCM per DMI, but there was no effect due to NFFS. Dietary treatments did not influence efficiency of use of feed $\mathrm{N}$ to milk N.

Dietary treatments did not influence ruminal $\mathrm{pH}$ profiles (Table 5), except that duration of $\mathrm{pH}<5.8$ was reduced by feeding NFFS in the CCS-based diet, resulting in a tendency for a $\mathrm{CS} \times \mathrm{NFFS}$ interaction $(P$ 
Table 4. Milk production and composition and efficiencies of DM and $\mathrm{N}$ use for milk production of early lactation Holstein dairy cows fed conventional or brown midrib corn silage without or with nonforage fiber sources

\begin{tabular}{|c|c|c|c|c|c|c|c|c|}
\hline Item & \multicolumn{4}{|c|}{$\operatorname{Diet}^{1}$} & $\mathrm{SE}$ & \multicolumn{3}{|c|}{ Significance of effect ${ }^{2}$} \\
\hline \multicolumn{9}{|l|}{ Yield, kg/d } \\
\hline Milk & 42.6 & 41.5 & 41.6 & 43.3 & 2.14 & 0.53 & 0.64 & 0.06 \\
\hline Fat & 1.23 & 1.24 & 1.13 & 1.04 & 0.110 & $<0.01$ & 0.25 & 0.20 \\
\hline $3.5 \% \mathrm{FCM}$ & 38.6 & 38.1 & 36.4 & 35.6 & 2.55 & 0.01 & 0.43 & 0.84 \\
\hline \multicolumn{9}{|l|}{ Milk composition, \% } \\
\hline Fat & 2.91 & 2.97 & $2.71^{\mathrm{a}}$ & $2.40^{\mathrm{b}}$ & 0.203 & $<0.01$ & 0.19 & 0.07 \\
\hline Protein & 2.80 & 2.84 & $2.82^{\mathrm{a}}$ & $2.78^{\mathrm{b}}$ & 0.039 & 0.17 & 0.82 & 0.04 \\
\hline Lactose & 3.55 & 3.53 & $3.48^{\mathrm{b}}$ & $3.69^{\mathrm{a}}$ & 0.199 & 0.48 & 0.20 & 0.11 \\
\hline MUN, mg/dL & 15.7 & 15.5 & 15.0 & 15.3 & 0.44 & 0.16 & 0.93 & 0.42 \\
\hline \multicolumn{9}{|l|}{ Efficiency } \\
\hline
\end{tabular}

${ }^{\mathrm{a}, \mathrm{b}}$ Means in the same row within CCS and BMRCS subgroups with different superscripts differ based on single degree of freedom contrasts $(P$ $<0.05)$.

${ }^{1}$ CCS-NFFS = conventional corn silage (CCS)-based diet without nonforage fiber sources (NFFS); CCS+NFFS = CCS-based diet with NFFS; BMRCS-NFFS = brown midrib corn silage (BMRCS)-based diet without NFFS; and BMRCS+NFFS = BMRCS-based diet with NFFS.

${ }^{2} \mathrm{CS}=$ effect of hybrids of CS in the diet (CCS vs. BMRCS); NFFS = effect of dietary NFFS (without vs. with NFFS); and INT = interaction between CS and NFFS.

${ }^{3}$ Efficiency of use of feed $\mathrm{N}$ to milk $\mathrm{N}=[$ (milk true protein, $\left.\mathrm{kg} / \mathrm{d} \div 0.93) \div 6.38\right] \div \mathrm{N}$ intake, $\mathrm{kg} / \mathrm{d}$.

$=0.07)$. Total VFA production and individual molar proportions were not affected by diets. Concentration of $\mathrm{NH}_{3}-\mathrm{N}$ tended $(P=0.10)$ to decrease due to feeding the BMRCS-based diet, which resulted from decreased $\mathrm{NH}_{3}-\mathrm{N}$ by NFFS.

\section{DISCUSSION}

\section{Characteristics of CS and Experimental Diets}

Reduced lignin concentration in BMRCS has been the hybrid's most notable nutritive benefit, because it can increase NDF digestibility in vivo. In this study, concentration of lignin was reduced by $28.5 \%$ in BMRCS compared with CCS, and in vitro NDF degradability of BMRCS increased by $25.7 \%$. Eastridge (1999) reported that, on average, BMRCS contained $34 \%$ less lignin and had $19 \%$ higher in situ or in vitro NDF degradability compared with non-BMR hybrids. Ebling and Kung (2004) reported a greater difference (55\%) in the concentration of lignin and a greater increase $(38 \%)$ in in vitro NDF degradability. In agreement with the data summarized by Eastridge (1999), we found no differences in nutrient components between CCS and BMRCS. In addition, although particle size distributions between CCS and BMRCS had different patterns, with slightly lower peNDF in BMRCS than CCS, the particle size estimates of both CS are within the recommendation of Kononoff et al. (2003).

Cows used in this study were fed a lower concentration of CS (28\% DM on average) with higher concentrations of $\mathrm{AH}$ (25\% DM on average) than diets fed in previous studies done with BMRCS (Taylor and Allen, 2005a; Weiss and Wyatt, 2006; Kung et al., 2008). What made our study unique was considering typical lactating dairy diets in the Intermountain West that contained high concentrations of AH with CS. Only a couple of studies published with BMRCS included any $\mathrm{AH}$ in the diets; for example, Ebling and Kung (2004) fed $8 \% \mathrm{AH}$ with $45 \%$ BMRCS and $10 \%$ alfalfa silage on DM basis, and in another study, Kung et al. (2008) fed $5 \%$ AH with $45 \%$ BMRCS and $5 \%$ alfalfa silage on DM basis. Others fed 31 to $60 \%$ BMRCS (DM basis), and alfalfa silage concentrations ranged from 8 to $13 \%$ with no AH in the diet at all (Oba and Allen, 2000a,b; Qiu et al., 2003).

The high quality AH used in our study was clean, bright green, and fine-stemmed with a chemical composition of $21.3,38.3$, and $26.7 \% \mathrm{DM}$ for $\mathrm{CP}, \mathrm{NDF}$, and ADF, respectively. Kung et al. (2008) used medium quality $\mathrm{AH}(16.8,43.9$, and $36.8 \%$ DM for $\mathrm{CP}$, $\mathrm{NDF}$, and ADF, respectively) in BMRCS TMR diets. Therefore, digestive and nutritive contributions by $\mathrm{AH}$ in the current study would be relatively high because 
Table 5. Ruminal fermentation characteristics of early lactation Holstein dairy cows fed conventional or brown midrib corn silage without or with nonforage fiber sources

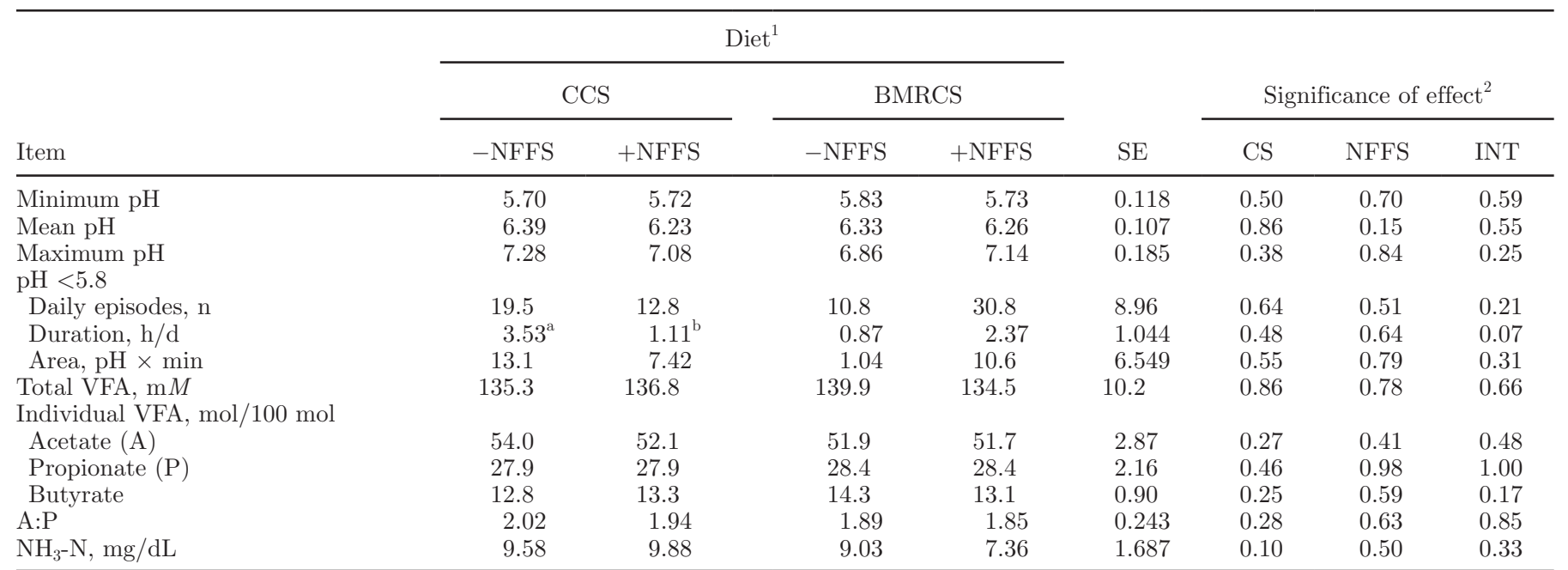

${ }^{\mathrm{a}, \mathrm{b}}$ Means in the same row within CCS and BMRCS subgroups with different superscripts differ based on single degree of freedom contrasts $(P$ $<0.05)$.

${ }^{1}$ CCS-NFFS = conventional corn silage (CCS)-based diet without nonforage fiber sources (NFFS); CCS+NFFS = CCS-based diet with NFFS; BMRCS-NFFS = brown midrib corn silage (BMRCS)-based diet without NFFS; and BMRCS+NFFS = BMRCS-based diet with NFFS.

${ }^{2} \mathrm{CS}=$ effect of hybrids of CS in the diet (CCS vs. BMRCS); NFFS = effect of dietary NFFS (without vs. with NFFS); and INT = interaction between CS and NFFS.

of its large dietary proportion as well as high nutritive quality.

\section{Nutrient Intake and Digestibility}

Because of the sizable increase of in vitro NDF degradability of BMRCS, we expected that the BMRCSbased diet would improve DMI and nutrient digestibilities. However, we did not detect any positive response on intake of DM and nutrients. Rather, BMRCS-based diets tended to decrease $(P<0.15) \mathrm{N}$ and fiber digestibilities. The negative effects of BMRCS on the digestibilities were unexpected, highlighting the weaknesses of the in vitro technique to predict in vivo response. Oba and Allen (2000b) reported that BMRCS TMR did not increase ruminal or total-tract NDF digestibility. Additionally, Taylor and Allen (2005a) reported that, although in vitro NDF degradability was 12.6 percentage units higher for BMRCS, in vivo ruminal and postruminal NDF digestibility of BMRCS TMR did not increase. These results suggest that although in vitro NDF degradability can be improved by BMRCS, in vivo response depends upon integration of several factors; for instance, DMI and ruminal passage rate are important in determining ruminal residence time, influencing ruminal digestion. Therefore, mixed results from in vitro and in vivo experiments make it difficult to formulate any accurate predictions for animals fed BMRCS (Taylor and Allen, 2005a).
The mechanism whereby a BMRCS-based diet tended to decrease $\mathrm{N}(P=0.11)$ and fiber digestibility $(P<$ 0.14 ) is difficult to explain. It is probable that relatively high nutritive quality of $\mathrm{AH}$ with fine chopping may increase passage rate, diluting potential effects of BMRCS in ruminal digestion, as was seen in increased in vitro NDF degradability (Figure 1).

Partial replacement of forage with NFFS resulted in similar ruminal NDF digestibility when diets contained equal NDF concentrations (Cunningham et al., 1993; Feng et al., 1993; Van Vuuren et al., 1993). The NDF in NFFS has been considered to be of higher digestibility than that of forage NDF, and total-tract NDF digestibility increased when soyhulls replaced forage or concentrate (Sarwar et al., 1991, 1992; Cunningham et al., 1993). However, if NFFS have lower undigestible NDF fraction compared with forages, the amount of potentially degradable NDF leaving the rumen may be greater when NFFS replace forage (Pantoja et al., 1994; Bhatti and Firkins, 1995). In our case, we believe that a high forage NDF concentration may eliminate potentially positive effects of NFFS. Forage NDF concentration in our study was 21.2 and $17.9 \%$, respectively, for diets without and with NFFS, and forage NDF contributed to 65 and $55 \%$ of dietary NDF, respectively. Replacing forage NDF with NFFS for pef ${ }_{8.0}$ may vary with changing forage chop length and fiber level or composition. As the mean particle length or NDF content of the forage increases, ruminal retention time and forage mat 
formation in the rumen increase, which may slow the passage rate of NFFS, thus enhancing fiber digestibility (Clark and Armentano, 1997). However, it seems that the positive effects of NFFS may be ineffective when diets contain appropriate forage or dietary NDF such as the high quality forage diets used in our study. When feeding forage NDF below 19\% DM, the NRC (2001) recommends increasing total dietary NDF by 2 percentage units for every 1-percentage-unit decrease below $25 \% \mathrm{DM}$ of total dietary NDF, and all diets tested in this study are within the NRC recommendation.

\section{Milk Production and Composition and Feed Efficiency}

Because of the lack of effects of BMRCS TMR on intake and their limited effects on digestibility, we did not expect any positive effects on milk production and feed efficiency due to feeding BMRCS-based diet. Productive performance of BMRCS diets have been inconsistent; milk yield and FCM yield were greater for cows consuming BMRCS TMR than for those fed CCS TMR (Tine et al., 2001; Ebling and Kung, 2004; Weiss and Wyatt, 2006), whereas increased production has not been observed in other studies (Greenfield et al., 2001; Qiu et al., 2003; Gehman et al., 2008).

In previous studies, yield of milk fat was not affected by CS hybrids, but milk fat percentage was reduced when BMRCS was fed in some studies (Oba and Allen, 2000a; Qiu et al., 2003; Weiss and Wyatt, 2006). Oba and Allen (2000a) observed an interaction between concentration of dietary NDF and CS hybrids for milk fat percentage; milk fat concentration was reduced when BMRCS was included in diets with $28 \%$ NDF, but was not affected when diets contained 38\% NDF. Milk fat depression due to low ruminal $\mathrm{pH}$ and acetate to propionate ratio is expected from cows consuming lower forage and diets of shorter particle size as observed by Grant et al. (1990) and Fischer et al. (1994). Diets in the present study contained approximately $32 \% \mathrm{NDF}$, meeting NRC (2001) requirements, and mean ruminal $\mathrm{pH}$ was 6.2 , indicating that all diets were adequate to maintain normal ruminal fermentation. However, the CCS-based diet produced an average of $0.15 \mathrm{~kg} / \mathrm{d}$ more milk fat than the BMRCS-based diets. Therefore, lower pef of BMRCS and possibly resultant lower pef of the BMRCS-based diet may decrease milk fat concentration and yield.

Low milk fat concentration ( $2.75 \%$ on average) in the current study is noticeable. Fracturing the corn kernels in CS has been shown to improve starch digestibility (Bal et al., 2000; Weiss and Wyatt, 2000), and both CCS and BMRCS were mechanically processed before ensiling. The processed CS may enhance ruminal starch digestion, leading to lower acetate to propionate ratio. Acetate to propionate ratios $<2.0$ are often associated with milk fat depression (Erdman, 1988), and in our study the ratio averaged 1.93 .

There is limited information in the scientific literature on the effects of feeding a mixture of soyhulls and beet pulp as NFFS on milk production by dairy cows. Clark and Armentano (1997) reported increased milk yield, milk protein yield, and milk protein concentration, but lower milk fat percentage and fat yield for cows fed low forage diets (30\% forage) with NFFS (mixture of whole cottonseed, distillers grains, and wheat middlings) than for cows fed high forage diets ( $60 \%$ forage). In the low forage diets, DMI, milk fat percentage, and milk fat yield all increased linearly as NDF concentration increased. Adding NDF from NFFS increased milk fat percentage and yield, but this increase was less than that expected compared with the increase of NDF from alfalfa silage. Pereira et al. (1999) reported that NFFS (mixture of wheat middlings, distillers grains, and corn gluten feed) were only $27 \%$ as effective as NDF from alfalfa silage in eliciting a milk fat concentration response. Hence, NFFS used in this study (8.4\% DM) were not effectively used to affect milk composition due to high forage NDF. Rather, the NFFS exerted a negative effect on milk fat concentration when added in the BMRCS-based diet.

\section{Ruminal Fermentation Characteristics}

In general, we did not find major effects of feeding a BMRCS-based diet on ruminal fermentation. In some studies (Block et al., 1981; Taylor and Allen, 2005b), BMRCS TMR reduced the acetate to propionate ratio in the rumen compared with CCS TMR by decreasing the molar proportion of acetate and increasing the propionate proportion. In contrast, BMRCS TMR did not affect the molar proportion of acetate (Oba and Allen, 2000a; Greenfield et al., 2001), and only increased the molar proportion of propionate in the experiment by Greenfield et al. (2001). Ruminal pH was similar among treatments in our study, but others reported that BMRCS TMR decreased ruminal $\mathrm{pH}$ (Oba and Allen, 2000a; Greenfield et al., 2001; Taylor and Allen, 2005b). In our study, minimum ruminal $\mathrm{pH}$ was maintained at least at 5.70, and $\mathrm{pH}<5.8$ rarely occurred, signifying that no dietary treatments interfered with ruminal fermentation due to adequate supply of forage NDF and its particle size. Diets for early lactating dairy cows often contain high levels of fermentable carbohydrate and low levels of fiber to maximize energy intake. However, feeding a high concentrate diet typically results in reduced ruminal $\mathrm{pH}$ and subsequent dysfunctions of ruminal fermentation. High quality for- 
ages, particularly $\mathrm{AH}$, used in the current study would provide efficient ruminal fermentation and digestibility. High quality $\mathrm{AH}$ is lower in NDF concentration and may not be adequate for milk fat production, but is generally thought to stimulate adequate rumination and saliva production and provide adequate natural buffering capacity, reducing the need for dietary buffers (Eickelberger et al., 1985).

Experimental cows used in this study maintained overall productive performance without any negative response on ruminal fermentation and digestibility, although we fed high forage diets to the early lactating dairy cows. Further research is needed on the effects of BMRCS and NFFS in high concentrate lactating diets that induce subacute ruminal acidosis to determine if they contribute to reducing metabolic risk and maintaining optimal ruminal fermentation in dairy cows.

Feeding NFFS did not change ruminal fermentation in this study. Similar to our findings, Pereira and Armentano (2000) reported that the addition of NFFS had no effect on the ratio of acetate to propionate or total VFA concentration when NFFS replaced a portion of forage and concentrate at 17.2 and $20 \%$ DM, respectively.

\section{CONCLUSIONS}

Despite a substantial increase in in vitro NDF degradation of BMRCS, feeding a BMRCS-based TMR compared with a CCS-based TMR had limited effects on intake, digestibility, and milk production when fed in high forage diets containing high quality $\mathrm{AH}$. When fed with BMRCS, feeding NFFS increased feed efficiency (milk/DMI), but decreased milk fat concentration. Feeding NFFS did not affect any productive performance parameter when fed in the CCS diet. Our results provide scientific evidence to support the common notion that high quality forage and forage NDF concentration beyond the NRC (2001) recommendation limit the potential effects of BMRCS and NFFS on lactational performance of dairy cows. One should be cautious of low milk fat concentration in this study due possibly to accelerated ruminal starch digestion, which may have resulted from mechanical processing of CS before ensiling and small particle size of diets due to fine chopping of AH. Overall, it is recommended to maintain proper particle size of $\mathrm{AH}$ although it has high nutritive quality when fed with BMRCS. Further research is needed to investigate the interactive effects of chop length of high quality AH with BMRCS at various dietary proportions in lactating diets on ruminal fermentation and its relation to lactational performance of dairy cows.

\section{ACKNOWLEDGMENTS}

This study was supported by funds from Cargill Animal Nutrition (Minneapolis, MN) and Utah State University Agricultural Experiment Station (Logan). The authors thank S. Durham (Ecology Center, Utah State University, Logan) for assistance with statistical analysis of the results and the staff of the Caine Dairy Center (Wellsville, UT) for their conscientious care of the experimental cows.

\section{REFERENCES}

AOAC. 2000. Official Methods of Analysis. Vol. 1 and 2. 17th ed. AOAC Int., Gaithersburg, MD.

Bal, M. A., R. D. Shaver, A. G. Jirovec, K. J. Shinners, and J. G. Coors. 2000. Crop processing and chop length of corn silage: Effects on intake, digestion, and milk production by dairy cows. J. Dairy Sci. 83:1264-1273.

Beauchemin, K. A., and W. Z. Yang. 2005. Effects of physically effective fiber on intake, chewing activity, and ruminal acidosis for dairy cows fed diets based on corn silage. J. Dairy Sci. 88:2117-2129.

Bhatti, S. A., and J. L. Firkins. 1995. Kinetics of hydration and functional specific gravity of fibrous feed by-product. J. Anim. Sci. 73:1449-1458.

Block, E., L. D. Muller, L. C. Griel Jr., and D. L. Garwood. 1981. Brown midrib-3 corn silage and heat extruded soybeans for early lactating dairy cows. J. Dairy Sci. 64:1813-1825.

Clark, P. W., and L. E. Armentano. 1997. Replacement of alfalfa NDF with a combination of non-forage fiber sources. J. Dairy Sci. 80:675-680.

Cunningham, K. D., M. J. Cecava, and T. R. Johnson. 1993. Nutrient digestion, nitrogen, and amino acid flows in lactating cows fed soybean hulls in place of forage or concentrate. J. Dairy Sci 76:3523-3535

Eastridge, M. L. 1999. Brown midrib corn silage. Pages 179-190 in Proc. Tri-State Dairy Nutrition Conf. Ohio State University, Columbus, $\mathrm{OH}$.

Ebling, T. L., and L. Kung Jr.. 2004. A comparison of processed conventional corn silage to unprocessed and processed brown midrib corn silage on intake, digestion, and milk production by dairy cows. J. Dairy Sci. 87:2519-2526.

Eickelberger, R. C., L. D. Muller, T. F. Sweeney, and S. M. Abrams, 1985. Addition of buffers to high quality alfalfa hay-based diets for dairy cows in early lactation. J. Dairy Sci. 68:1722-1731.

Erdman, R. A. 1988. Dietary buffering requirements of the lactating dairy cow: A review. J. Dairy Sci. 71:3246-3266.

Feng, P., W. H. Hoover, T. K. Miller, and R. Blauwiekel. 1993. Interactions of fiber and nonstructural carbohydrates on lactation and ruminal function. J. Dairy Sci. 76:1324-1333

Fischer, J. M., J. G. Buchanan-Smith, C. Campbell, D. G. Grieve, and O. B. Allen. 1994. Effects of forage particle size and long hay for cows fed total mixed rations based on alfalfa and corn. J. Dairy Sci. $77: 217-229$.

Gehman, A. M., P. J. Kononoff, C. R. Mullins, and B. N. Janicek 2008. Evaluation of nitrogen utilization and the effects of monensin in dairy cows fed brown midrib corn silage. J. Dairy Sci 91:288-300.

Grant, R. J., V. F. Colenbrander, and D. R. Mertens. 1990. Milk fat depression in dairy cows: role of silage particle size. J. Dairy Sci. 73:1834-1842.

Greenfield, T. L., R. L. Baldwin, R. A. Erdman, and K. R. McLeod. 2001. Ruminal fermentation and intestinal flow of nutrients by lactating cows consuming brown midrib corn silages. J. Dairy Sci. 84:2469-2477

Hall, M. B., A. N. Pell, and L. E. Chase. 1998. Characteristics of neutral detergent-soluble fiber fermentation by mixed ruminal microbes. Anim. Feed Sci. Technol. 70:23-39. 
Howard, W. T. 1994. Alfalfa vs. corn silage: Balancing rations. Pages 98-107 in Proc. Wisconsin Forage Council's 18th Forage Production and Use Symposium. Wisconsin Forage Council, Madison.

Ipharraguerre, I. R., and J. H. Clark. 2003. Soyhulls as an alternative feed for lactating dairy cows: A review. J. Dairy Sci. 86:10521073.

Kononoff, P. J., A. J. Heinrichs, and D. A. Buckmaster. 2003. Modification of the Penn State forage and total mixed ration separator and the effects of moisture content on its measurements. J. Dairy Sci. $86: 1858-1863$.

Kung, L. Jr., B. M. Moulder, C. M. Mulrooney, R. S. Teller, and R. J. Schmidt. 2008. The effect of silage cutting height on the nutritive value of a normal corn silage hybrid compared with brown midrib corn silage fed to lactating cows. J. Dairy Sci. 91:1451-1457.

Lammers, B. P., D. R. Buckmaster, and A. J. Heinrichs. 1996. A simple method for the analysis of particle size of forage and total mixed rations. J. Dairy Sci. 79:922-928.

Littell, R. C., P. R. Henry, and C. B. Ammerman. 1998. Statistical analysis of repeated measures data using SAS procedures. J. Anim. Sci. 76:1216-1231.

Maekawa, M., K. A. Beauchemin, and D. A. Christensen. 2002. Chewing activity, saliva production, and ruminal $\mathrm{pH}$ of primiparous and multiparous lactating dairy cows. J. Dairy Sci. 85:1176-1182.

Nocek, J. E. 1997. Bovine acidosis: Implications on laminitis. J. Dairy Sci. 80:1005-1028.

NRC. 2001. Nutrient Requirements of Dairy Cattle. 7th rev. ed. Natl. Acad. Sci., Washington, DC.

Oba, M., and M. S. Allen. 1999. Effects of brown midrib 3 mutation in corn silage on dry matter intake and productivity of high yielding dairy cows. J. Dairy Sci. 82:135-142.

Oba, M., and M. S. Allen. 2000a. Effects of brown midrib 3 mutation in corn silage on productivity of dairy cows fed two concentrations of dietary neutral detergent fiber: 1. Feeding behavior and nutrient utilization. J. Dairy Sci. 83:1333-1341.

Oba, M., and M. S. Allen. 2000b. Effects of brown midrib 3 mutation in corn silage on productivity of dairy cows fed two concentrations of dietary neutral detergent fiber: 3 . Digestibility and microbial efficiency. J. Dairy Sci. 83:1350-1358.

Pantoja, J., J. L. Firkins, M. L. Eastridge, and B. L. Hull. 1994. Effects of fat saturation and source of fiber on site of nutrient digestion and milk production by lactating dairy cows. J. Dairy Sci. 77:2341-2356.

Penner, G. B., K. A. Beauchemin, and T. Mutsvangwa. 2006. An evaluation of the accuracy and precision of a stand-alone submersible continuous ruminal $\mathrm{pH}$ measurement system. J. Dairy Sci. 89:2132-2140.

Pereira, M. N., and L. E. Armentano. 2000. Partial replacement of forage with nonforage fiber sources in lactating cow diets. II. Digestion and rumen function. J. Dairy Sci. 83:2876-2887.
Pereira, M. N., E. F. Garrett, G. R. Oetzel, and L. E. Armentanto. 1999. Partial replacement of forage with nonforage fiber sources in lactating cow diets. I. Performance and health. J. Dairy Sci. $82: 2716-2730$.

Qiu, X., M. L. Eastridge, and Z. Wang. 2003. Effects of corn silage hybrid and dietary concentration of forage NDF on digestibility and performance by dairy cows. J. Dairy Sci. 86:3667-3674.

Rhine, E. D., G. K. Sims, R. L. Mulvaney, and E. J. Pratt. 1998. Improving the Bertholot reaction for determining ammonium in soil extracts and water. Soil Sci. Soc. Am. J. 62:473-480.

Sarwar, M., J. L. Firkins, and M. L. Eastridge. 1991. Effect of replacing neutral detergent fiber of forage with soyhulls and corn gluten feed for dairy heifers. J. Dairy Sci. 74:1006-1017.

Sarwar, M., J. L. Firkins, and M. L. Eastridge. 1992. Effects of varying forage and concentrate carbohydrates on nutrient digestibilities and milk production by dairy cows. J. Dairy Sci. 75:1533-1542.

SAS Institute. 2001. SAS System for Microsoft Windows. Release 8.2. SAS Institute Inc., Cary, NC.

Stern, M. D., and C. J. Zeimer. 1995. By-product feeds as energy sources for ruminants. Prof. Anim. Sci. 11:51-57.

Taylor, C. C., and M. S. Allen. 2005a. Corn grain endosperm type and brown midrib 3 corn silage: Site of digestion and ruminal digestion kinetics in lactating cows. J. Dairy Sci. 88:1413-1424.

Taylor, C. C., and M. S. Allen. 2005b. Corn grain endosperm type and brown midrib 3 corn silage: Ruminal fermentation and N partitioning in lactating cows. J. Dairy Sci. 88:1434-1442.

Tine, M. A., K. R. McLeod, R. A. Erdman, and R. L. Baldwin VI. 2001. Effects of brown midrib corn silage on the energy balance of dairy cattle. J. Dairy Sci. 84:885-895.

Van Keulen, J., and B. A. Young. 1977. Evaluation of acid-insoluble ash as a natural marker in ruminant digestibility studies. J. Anim. Sci. 44:282-287.

Van Soest, P. J., J. B. Robertson, and B. A. Lewis. 1991. Methods of dietary fiber, neutral detergent fiber and non-starch polysaccharides in relation to animal nutrition. J. Dairy Sci. 74:3583-3597.

Van Vuuren, A. M., C. J. Van Der Koelen, and J. Vroons-De Bruin. 1993. Ryegrass versus corn starch or beet pulp fiber diet effects on digestion and intestinal amino acids in dairy cows. J. Dairy Sci. 76:2692-2700

Weiss, W. P., and D. J. Wyatt. 2000. Effect of oil content and kernel processing of corn silage on digestibility and milk production by dairy cows. J. Dairy Sci. 83:351-358.

Weiss, W. P., and D. J. Wyatt. 2006. Effect of corn silage hybrid and metabolizable protein supply on nitrogen metabolism of lactating dairy cows. J. Dairy Sci. 89:1644-1653. 